\title{
PERUBAHAN KARAKTERISTIK BUBUK BUAH PANDAN (Pandanus tectorius) SELAMA PENYIMPANAN PADA PERLAKUAN JENIS KEMASAN DAN SUHU PENYIMPANAN
}

\author{
I Komang Budha Astawa, Ni Made Wartini*, I Wyn Gede Sedana Yoga \\ PS Teknologi Industri Pertanian, Fakultas Teknologi Pertanian, Universitas Udayana, Kampus Bukit \\ Jimbaran, Badung, Kode pos : 80361; Telp/Fax : (0361) 701801.
}

Diterima 21 Januari 2018 / Disetujui 04 Februari 2019

\begin{abstract}
Pandan is part of the marine pandanus plants that are yellow to orange. Pandan fruit has the potential to be a source of natural dyes yellow and orange. Dyes obtained from pandan fruit are unstable. The purpose of this study was to determine the effect of the type of packaging and storage temperature on the characteristics of fruit powder and to determine the type of packaging and the best temperature for storing pandan powder. The design in this study used a completely randomized design with two factors. Factor I is a packaging treatment consisting of 4 types of packaging, namely polypropylene, polyethylene, aluminum foil, and brown paper. Factor II is the temperature consisting of two levels, namely $4^{\circ} \pm 2^{\circ} \mathrm{C}$ and $27^{\circ} \pm 2^{\circ} \mathrm{C}$. The results showed that the temperature had a very significant effect $(P<0,01)$ on water content and total carotene but did not have a significant effect $(P>0,05)$ on the reddish value $\left(L^{*}\right)$, the reddish value $\left(a^{*}\right)$, reddish value $\left(b^{*}\right)$. The packaging type has a very significant effect $(P<0.01)$ on water content and total carotene, but does not have a significant effect $(P>0,05)$ on the reddish value $\left(L^{*}\right)$, the reddish value $\left(a^{*}\right)$, reddish value $\left(b^{*}\right)$, the most stable treatment in aluminum foil and cold temperatures $4 \pm 2^{\circ} \mathrm{C}$ for 4 weeks of storage, with the percentage of moisture content, total carotenoids, color intensity $\left(L^{*}, a^{*}, b^{*}\right)$ in the amount of $14.00 \%, 17.86 \%, 34,89 \%, 43,88 \%, 22,76 \%$ Keywords: pandanus (Pandanus tectorius), carotene, type of packaging, storage temperature.
\end{abstract}

*Korespondensi Penulis:

Email : md_wartini@unud.ac.id 


\section{PENDAHULUAN}

Buah pandan merupakan bagian dari tanaman pandan laut yang memiliki warna kuning hingga oranye (Ratih et al., 2015). Buah pandan memiliki kandungan kimia yang terdiri dari air, karbohidrat, beta karoten dan vitamin $\mathrm{C}$, serta sejumlah kecil protein, lemak, dan serat (Englbelger et al., 2005). Penelitian tentang buah pandan laut telah banyak dilakukan, diantaranya sebagai bahan pewarna alami dan sebagai sumber pektin. Buah pandan yang memiliki warna kuning hingga oranye berpotensi menjadi sumber pewarna alami kuning dan oranye. Selain memberikan zat warna, buah pandan juga mengandung karotenoid yang berfungsi sebagai pro vitamin A yang bersifat sebagai antioksidan (Englbelger, et al., 2005). Zat warna dari buah pandan dapat diperoleh dengan cara melakukan ekstraksi buah pandan. Penelitian buah pandan menjadi zat warna telah banyak dilakukan, diantaranya Antari et al. (2015), Ratih et al. (2015), Sari et al. (2015) Cahyanti et al. (2015), dan Yudharini et al. (2016). Karakteristik zat warna yang diperoleh dari buah pandan yaitu berupa pasta kental, berwarna kuning sampai oranye, mengandung karotenoid, serta memiliki sifat yang tidak stabil. Selama ini belum dilakukan penelitian mengenai karakteristik bubuk buah pandan yang disimpan dalam jenis kemasan dan suhu yang berbeda.

Beberapa penelitian mengenai stabilitas karotenoid telah dilakukan, diantaranya adalah Oktafia et al. (2015) mengenai stabilitas karotenoid dari ekstrak kulit buah alkesa. Penelitian Aryayustama et al. (2018) penyimpanan ekstrak terbaik pada perlakuan $4^{\circ} \pm 2^{\circ} \mathrm{C}$ dalam kondisi gelap merupakan perlakuan terbaik dengan laju total penurunan total karotenoid sekitar $13,47 \%$. Pengaruh jenis kemasan dan suhu penyimpanan terhadap bubuk buah pandan paling stabil pada kondisi penyimpanan
$4 \pm 2^{\circ} \mathrm{C}$ dan pengemas aluminium foil selama 4 minggu penyimpanan. Menurut Robertson (1993) polipropilen memiliki densitas yang lebih rendah dan memiliki titik lunak lebih tinggi dibandingkan polietilen, permeabilitas gas sedang, tahan terhadap lemak dan bahan kimia, Rochman (2007) menjelaskan bahwa Plastik propilen lebih kaku, terang dan kuat dibanding polietilen. Pengemasan plastik menurut (Shahnawaz et al., 2012) dapat menyebabkan adanya modifikasi atmosfir dengan menekan proses respirasi buah tomat. Menurut BPPHP (2002) tujuan pengemasan yaitu menghambat penurunan bobot, meningkatkan citra produk, menghindari atau mengurangi kerusakan pada waktu pengangkutan, dan sebagai alat promosi. Penelitian Andriyani et al. (2016) menunjukkan bahwa ekstrak karotenoid dari ekstrak lamun laut (Enhalus acoroides) lebih stabil pada suhu dingin dibandingkan pada suhu ruang selama penyimpanan. Kondisi penyimpanan dan aplikasi pada produk sangat menentukan stabilitas karotenoid dalam suatu bahan. Sehingga penelitian tentang pengaruh jenis kemasan dan suhu penyimpanan terhadap karakteristik bubuk buah pandan (Pandanus tectorius) perlu dilakukan dengan tujuan untuk mengetahui pengaruh jenis kemasan dan suhu penyimpanan terhadap karakteristik bubuk buah pandan dan menentukan jenis kemasan dan suhu terbaik untuk menyimpan bubuk buah pandan.

\section{METODE PENELITIAN}

\section{Tempat dan Waktu Penelitian}

Penelitian ini dilakukan di

Laboratorium Rekayasa Proses dan Pengendalian Mutu dan Laboratorium Analisis Pangan, Fakultas Teknologi Pertanian, Universitas Udayana dari November sampai dengan Desember 2017.

\section{Alat dan Bahan}


Peralatan yang digunakan dalam penelitian ini yaitu : spektrofotometer UVVis thermo, color reader (Colorimeter PCECSM 1, PCE-CSM 2 and PCE-CSM 4), sealer, pisau, pemarut, baskom, oven (Blue M OV-520C-2), blender (philip), ayakan 60 mesh, botol timbang, desikator, pinset, timbangan analitik (Shimadzu ATY224), spatula, labu ukur, pipet volume, erlemeyer, gelas ukur, magnetik stiner, tabung reaksi, corong pisah, polipropilen, polietilen, aluminium foil dan kertas coklat.

Bahan yang digunakan dalam penelitian ini terdiri dari bahan baku dan bahan kimia. Bahan baku yaitu buah pandan (Pandanus tectorius) dengan kriteria warna oranye sampai merah dengan berat buah pandan per pandan 1,5 - $2 \mathrm{~kg}$ yang diperoleh di Desa Delod Brawah, Kecamatan Mendoyo, Kabupaten Jembrana. Bahan kimia yang digunakan semuanya memiliki grade PA (Pro Analis) dengan merk Merck.

\section{Rancangan Percobaan}

Percobaan ini adalah percobaan faktorial 2 faktor menggunakan Rancangan Acak Lengkap (RAL) dengan perlakuan jenis pengemas sebagai faktor I dan suhu penyimpanan sebagai faktor II. Faktor I jenis pengemas terdiri atas 4 jenis yaitu : Polipropilen, Polietilen, Aluminium foil, Kertas coklat. Faktor II suhu penyimpanan terdiri atas 2 taraf yaitu $4^{\circ} \mathrm{C} \pm 2^{\circ} \mathrm{C}$ dan suhu ruang $27^{\circ} \mathrm{C} \pm 2^{\circ} \mathrm{C}$.

Dari rancangan tersebut diperoleh 8 unit perlakua yang diulang sebanyak 2 kali sehingga menjadi 16 unit percobaan. Data yang diperoleh dianalisis dengan sidik ragam atau Analysis of Varians (ANOVA). Jika terdapat pengaruh perlakuan terhadap variabel maka dilakukan uji beda (Duncan). Analisis dilakukan dengan minitab 17. Penentuan perlakuan terbaik didasarkan perlakuan yang mampu mempertahankan kandungan karotenoid.

\section{Pelaksanaan Penelitian \\ Persiapan sampel bubuk buah pandan (Yudharini et al., 2016)}

Persiapan sampel diawali dengan melakukan sortasi pada buah pandan. Selanjutnya, dilakukan pengecilan ukuran dan dikeringkan dengan menggunakan oven pada suhu $50 \pm 5^{\circ} \mathrm{C}$ sampai mudah diblender (kadar air mencapai $\pm 8 \%$ ). Buah pandan yang sudah kering selanjutnya diblender dan diayak menggunakan ayakan 60 mesh. Kemudian disimpan dahulu pada frezeer sebelum digunakan.

\section{Pengemasan bubuk buah pandan}

Bubuk buah pandan sebelumnya dihomogenkan dan dioven pada suhu $\pm 50^{\circ} \mathrm{C}$ agar mencapai kadar air $\pm 8 \%$, karena sebelumnya bubuk disimpan dalam lemari pendingin. Bubuk ditimbang sebanyak $5 \mathrm{~g}$ dikemas dengan menggunakan kemasan polipropilen, polietilen, aluminium foil dan kertas coklat. Pengemasan dengan polipropilen dan polietilen menggunakan alat sealer sebagai alat bantun, sedangkan pengemasan dengan aluminium foil dan kertas coklat menggunakan lakban 2 sisi, yang dibentuk segi empat. Kemudian pada atas kemasan diberi lakban 2 sisi sebagai penutup kemasan. Ukuran kemasan yang digunakan yaitu $10 \mathrm{~cm}$ x $17 \mathrm{~cm}$ dan dengan ketebalan pada masing-masing kemasan ialah $0,05 \mathrm{~mm}$ diukur menggunakan micrometerscrup dan tebal aluminium foil adalah $0,03 \mathrm{~mm}$. Selanjutnya disimpan pada suhu sesuai perlakuan, masing masing kombinasi perlakuan disiapkan 4 unit percobaan sesuai dengan pengamatan yang dilakukan (setiap 1 minggu) selama 4 minggu.

\section{Variabel yang Diamati \\ Kadar Air (Sudarmadji et al., 1997)}

Kadar air bubuk buah pandan dilakukan menurut Sudarmadji et al. (1997). Botol timbang dikeringkan terlebih dahulu 
selama 1 jam dalam oven pada suhu $105^{\circ} \mathrm{C}$, lalu didinginkan dalam desikator dan kemudian beratnya ditimbang lalu ditambahkan sampel seberat 2 gram (a), kemudian dimasukkan ke dalam oven selama 4 jam pada suhu $100^{\circ} \mathrm{C}$, lalu didinginkan dalam desikator selama 15 menit dan ditimbang kembali, dan dioven setiap 1 jam dan berulang ulang hingga mencapai berat konstan atau berat selisih dengan sebelum dan sesudah dioven berturut turut $0,2 \mathrm{mg}$ (b). Adapun rumus penentuan kadar air sebagai berikut:

$$
\text { Kadar Air }=\frac{(a-b)}{a} \times 100 \%
$$

\section{Kadar total karotenoid (Muchtadi, 1989)}

Kadar total karotenoid ekstrak buah pandan dilakukan dengan menggunakan metode dari Muchtadi (1989) dengan cara pembuatan kurva standard dan analisis total karotenoid. Pembuatan kurva standar dilakukan dengan menimbang $25 \mathrm{mg} \beta$ karoten murni kemudian dilarutkan dengan 0,25 mL kloroform dan diencerkan menjadi $25 \mathrm{~mL}$ dengan petroleum benzena. Larutan kemudian dibagi sebanyak 0,5, 1, 2, 2,5 dan $3 \mathrm{~mL}$ ke dalam tabung reaksi yang terpisah dan ditambahkan dengan $0,3 \mathrm{~mL}$ aseton.
Larutan kemudian diencerkan sampai tanda tera $10 \mathrm{~mL}$ dengan petroleum benzen sehingga diperoleh konsentrasi standar $\beta$ karoten $0,005,0,01,0,02,0,025$ dan 0,03 $\mathrm{mg} / \mathrm{mL}$. Absorbansi diukur pada panjang gelombang $450 \mathrm{~nm}$ dengan menggunakan 0,3 $\mathrm{mL}$ aseton yang diencerkan dengan petroleum benzen sebagai blanko kemudian grafik dibuat untuk menghubungkan antara absorbansi dengan konsentrasi $\beta$-karoten. Analisis karotenoid pada sampel dilakukan dengan menimbang sampel sebanyak kurang lebih 0,002 g yang dimasukkan ke dalam tabung reaksi kemudian ditambahkan pelarut $5 \mathrm{~mL}$ petroleum benzena dan $5 \mathrm{~mL}$ aseton kemudian divortex dan disaring menggunakan kertas saring kasar. Hasil saringan dimasukkan ke dalam labu pemisah dan dibilas dengan akuades sebanyak $45 \mathrm{~mL}$. Air pembilas dibuang dan bagian berwarna ditampung dalam tabung reaksi dan ditambahkan kurang lebih $0,5 \quad \mathrm{~g} \mathrm{Na}_{2} \mathrm{SO}_{4}$ kemudian divortex. Bagian bening diambil sebanyak $2 \mathrm{~mL}$ dan ditambahkan petroleum benzena sampai volume $5 \mathrm{~mL}$ kemudian diukur absorbansi pada panjang gelombang $450 \mathrm{~nm}$. Penentuan kadar total karotenoid dapat dihitung dengan rumus sebagai berikut:

$$
\text { Kadar total karotenoid }(\%)=\frac{X \frac{m g}{100} m L \times f p \times 100 \%}{\text { konsentrasi sampel }(m g / 100 m L)}
$$

Keterangan : $\mathrm{X}=$ hasil yang diperoleh dari regresi kurva standar, $\mathrm{Fp}=$ faktor pengenceran

\section{Intensitas warna (Weaver, 1996)}

Pengukuran intensitas warna dari ekstrak buah pandan dilakukan dengan menggunakan color reader menurut sistem $\mathrm{L}^{*}, \mathrm{a}^{*}, \mathrm{~b}^{*}$. (Weaver, 1996).

\section{Uji organolaptik( Meilgaard et al., 1999)}

Uji kesukaan dilakukan terhadap warna dan tekstur bubuk buah pandan. Menurut Meilgaard et al., 1999, dilakukan tujuan uji tersebut adalah untuk mengetahui kesukaan terhadap warna dan tekstur bubuk buah pandan yang paling disukai oleh panelis.
Pengujian menggunakan 7 skala yaitu dari 1 - $7(1=$ sangat tidak suka, $2=$ tidak suka, $3=$ agak tidak suka, $4=$ netral, $5=$ agak suka, $6=$ suka, $7=$ sangat suka). Panelis yang digunakan adalah mahasiswa FTP yang diasumsikan panelis tidak terlatih dan bisa mewakili pendapat umum atau populasi tertentu, dengan jumlah panelis sebanyak 25 orang.

\section{HASIL DAN PEMBAHASAN}

Semua perlakuan kemasan dan suhu 
pada penyimpanan bubuk dari buah pandan mengakibatkan peningkatan pada kadar air pada bubuk. Hasil analisis ragam kadar air menunjukan bahwa perlakuan suhu berpengaruh sangat nyata $(\mathrm{P}<0,01)$ untuk setiap minggunya. Perlakuan kemasan menunjukkan pengaruh sangat nyata
$(\mathrm{P}<0,01)$ pada setiap minggunya. Interaksi kedua perlakuan berpengaruh tidak nyata $(\mathrm{P}$ $>0,05)$ pada minggu ke-1, dan 4 tetapi berpengaruh nyata $(\mathrm{P}<0,05)$ pada minggu ke2, dan 3. Rerata \% kadar air selama penyimpanan dapat dilihat pada Tabel 1 .

Tabel 1. Rerata(\%) kadar air bubuk buah pandan pada minggu ke- 2 dan 3.

\begin{tabular}{lccc}
\hline Jenis Kemasan & & \multicolumn{2}{c}{ Waktu simpan(Minggu ke-) } \\
\cline { 3 - 4 } Suhu $\left({ }^{\mathbf{0}} \mathbf{C}\right)$ & & $\mathbf{2}$ & $\mathbf{3}$ \\
\hline Polipropilen & $\mathbf{4} \pm \mathbf{2}$ & $8,92 \pm 0,02 \mathrm{a}$ & $9,27 \pm 0,09 \mathrm{a}$ \\
Polietilen & $\mathbf{4} \pm \mathbf{2}$ & $9,08 \pm 0,11 \mathrm{a}$ & $9,34 \pm 0,06 \mathrm{a}$ \\
Aluminium foil & $\mathbf{4} \pm \mathbf{2}$ & $8,33 \pm 0,04 \mathrm{a}$ & $8,60 \pm 0,01 \mathrm{~b}$ \\
Kertas coklat & $\mathbf{4} \pm \mathbf{2}$ & $10,01 \pm 0,10 \mathrm{~b}$ & $10,06 \pm 0,07 \mathrm{~b}$ \\
Polipropilen & $\mathbf{2 7} \pm \mathbf{2}$ & $10,16 \pm 0,04 \mathrm{c}$ & $10,31 \pm 0,02 \mathrm{c}$ \\
Polietilen & $\mathbf{2 7} \pm \mathbf{2}$ & $9,46 \pm 0,13 \mathrm{~cd}$ & $9,85 \pm 0,02 \mathrm{c}$ \\
Aluminium foil & $\mathbf{2 7} \pm \mathbf{2}$ & $8,58 \pm 0,03 \mathrm{de}$ & $8,98 \pm 0,06 \mathrm{~d}$ \\
Kertas coklat & $\mathbf{2 7} \pm \mathbf{2}$ & $10,04 \pm 0,14 \mathrm{e}$ & $10,39 \pm 0,08 \mathrm{e}$ \\
\hline
\end{tabular}

Keterangan: Angka yang diikuti huruf sama pada baris menunjukkan berpengaruh nyata $(\mathrm{P}<0,05)$.

Tabel 2. Rerata(\%) kadar air bubuk buah pandan pada minggu ke- 1 .

\begin{tabular}{lccc}
\hline \multirow{2}{*}{ Jenis kemasan } & \multicolumn{3}{c}{ Minggu ke- 1 } \\
& $\mathbf{4 \pm 2}$ & $\mathbf{S u h u}\left({ }^{\mathbf{C}} \mathbf{C}\right)$ & Rerata \\
\hline Polipropilen & 8,60 & 9,49 & $9,04 \pm 0,63 \mathrm{a}$ \\
Polietilen & 8,71 & 9,09 & $8,90 \pm 0,27 \mathrm{~b}$ \\
Aluminium foil & 8,18 & 8,33 & $8,25 \pm 0,11 \mathrm{~b}$ \\
Kertas coklat & 9,29 & 9,81 & $9,55 \pm 0,36 \mathrm{c}$ \\
\hline \multicolumn{1}{c}{ Rerata } & $34,77 \pm 0,46 \mathrm{a}$ & $36,71 \pm 64 \mathrm{~b}$ & \\
\hline
\end{tabular}

Keterangan: Angka yang diikuti huruf pada kolom yang sama menunjukkan berpengaruh tidak nyata $(\mathrm{P}>0,05)$.

Tabel 3. Rerata(\%) kadar air bubuk buah pandan pada minggu ke- 4.

\begin{tabular}{|c|c|c|c|}
\hline \multirow{3}{*}{ Jenis kemasan } & \multicolumn{2}{|c|}{ Minggu ke -4} & \multirow{3}{*}{ Rerata } \\
\hline & \multicolumn{2}{|c|}{$\operatorname{Suhu}\left({ }^{\circ} \mathbf{C}\right)$} & \\
\hline & $4 \pm 2$ & $27 \pm 2$ & \\
\hline Polipropilen & 9,52 & 10,48 & $10,00 \pm 0,68 \mathrm{a}$ \\
\hline Polietilen & 9,65 & 10,29 & $9,97 \pm 0,45 b$ \\
\hline Aluminium foil & 9,12 & 9,28 & $9,20 \pm 0,11 b$ \\
\hline Kertas coklat & 10,42 & 10,87 & $10,640,32 \mathrm{c}$ \\
\hline Rerata & $38,70 \pm 0,54 c$ & $40,92 \pm 0,6$ & \\
\hline
\end{tabular}

Keterangan: Angka yang diikuti huruf pada kolom yang sama menunjukkan berpengaruh tidak nyata $(\mathrm{P}>0,05)$. 


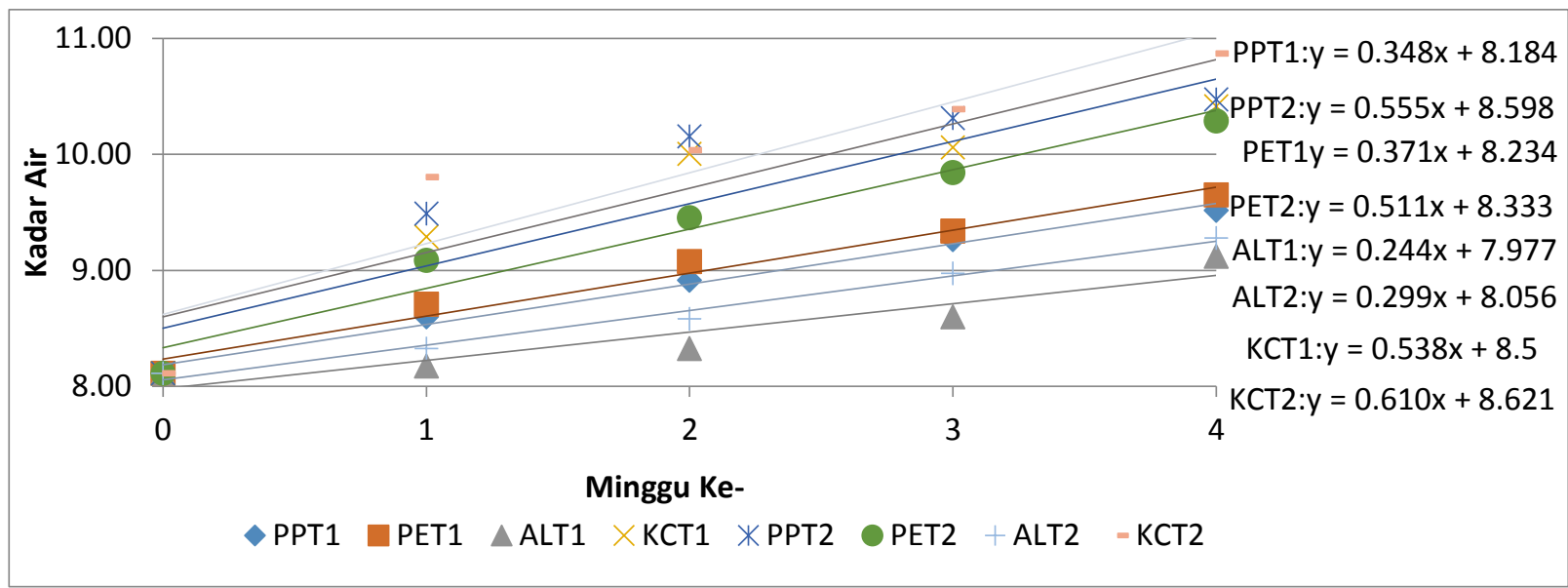

Gambar 1. Grafik peningkatan kadar air bubuk buah pandan selama penyimpanan pada perlakuan kemasan dan suhu.

Kadar air bubuk buah pandan yang belum diperlakukan (kontrol) adalah 8,11\%. Peningkatan kadar air untuk masing-masing perlakuan polipropilen $4^{\circ} \pm 2^{\circ} \mathrm{C}$, polietilen $4^{\circ} \pm 2^{\circ} \mathrm{C}$, aluminium foil $4^{\circ} \pm 2^{\circ} \mathrm{C}$, kertas coklat $4^{\circ} \pm 2^{\circ} \mathrm{C}$, polipropilen $27^{\circ} \pm 2^{\circ} \mathrm{C}$, polietilen $27^{\circ} \pm 2^{\circ} \mathrm{C}$, aluminium foil $27^{\circ} \pm 2^{\circ} \mathrm{C}$, kertas coklat $27^{\circ} \pm 2^{\circ} \mathrm{C}$ dari kontrol hingga minggukeempat berturut - turut adalah $18,97 \%, 20,63 \%, 14,00 \%, 30.19 \%, 30,94 \%$, $28,63 \%, 16,00 \%$, dan $35,88 \%$. Perlakuan aluminium foil $4^{\circ} \pm 2^{\circ} \mathrm{C}$ merupakan perlakuan yang mengakibatkan peningkatan terkecil yaitu sebesar $14,00 \%$. Hal ini menunjukkan bahwa kadar air pada bubuk buah pandan paling stabil pada perlakuan tersebut. Hal ini berkaitan dengan sifat aluminium foil yang memiliki permeabilitas yang berbeda dengan polipropilen, polietilen dan kertas coklat. Nilai permeabilitas berturut turut $0,5749 \mathrm{~g} / \mathrm{m}^{2} /, \quad 0,656 \mathrm{~g} / \mathrm{m}^{2}, \quad 0,822 \mathrm{~g} / \mathrm{m}^{2}$ dan $2,695 \mathrm{~g} / \mathrm{m}^{2}$. Pada suatu bahan pengemas yang memiliki tingkat permeabilitas yang rendah dapat menahan udara dan uap air yang dapat merusak bahan pangan dalam kemasan. Perlakuan kertas coklat $27^{\circ} \pm 2^{\circ} \mathrm{C}$ menunjukkan peningkatan terbesar dibandingkan perlakuan lainnya yaitu sebesar $35,88 \%$. Hal ini menunjukkan bahwa kadar air pada bubuk dari buah pandan paling tidak stabil pada perlakuan tersebut. Laju kenaikan kadar air paling tinggi terjadi pada minggu ke- 4 pada kemasan kertas coklat, semakin tinggi suhu penyimpanan maka laju peningkatan kadar air semakin rendah bahkan akan mengalami penurunan. Menurut Sewald dan Devries (2009), Produk yang dikemas mengalami perubahan kadar air relatif lambat tetapi pada suatu waktu dapat mengalami perubahan signifikan pada periode waktu yang singkat.

\section{Kadar Total Karotenoid Ekstrak Buah Pandan}

Semua perlakuan kemasan dan suhu pada penyimpanan bubuk dari buah pandan mengakibatkan penurunan pada jumlah total karotenoid pada bubuk. Hasil analisis ragam total karotenoid menunjukan bahwa perlakuan suhu berpengaruh sangat nyata $(\mathrm{P}<0,01)$ pada setiap minggunya. Perlakuan kemasan menunjukkan pengaruh sangat nyata $(\mathrm{P}<0,01)$ pada setiap minggunya. Interaksi kedua perlakuan berpengaruh nyata $(\mathrm{P}<0,05)$ pada minggu ke-1, 3, dan 4 tetapi tidak berpengaruh nyata $(\mathrm{P}>0,05)$ pada minggu ke-2. Rerata \% total karotenoid selama penyimpanan dapat dilihat pada Tabel 4. 
Tabel 4. Rerata(\%) total karotenoid karoten bubuk buah pandan pada minggu ke- 1, 3 dan 4.

\begin{tabular}{lcccc}
\hline Jenis Kemasan & & \multicolumn{3}{c}{ Waktu simpan(Minggu ke-) } \\
\cline { 3 - 5 } Suhu $\left({ }^{\mathbf{0}} \mathbf{C}\right)$ & & $\mathbf{1}$ & $\mathbf{3}$ & $\mathbf{4}$ \\
\hline Polipropilen & $\mathbf{4 \pm 2}$ & $0,39 \pm 0,01 \mathrm{a}$ & $0,30 \pm 0,04 \mathrm{a}$ & $0,27 \pm 0,03 \mathrm{a}$ \\
Polietilen & $\mathbf{4 \pm 2}$ & $0,37 \pm 0,01 \mathrm{ab}$ & $0,24 \pm 0,02 \mathrm{ab}$ & $0,21 \pm 0,01 \mathrm{a}$ \\
Aluminium foil & $\mathbf{4} \pm \mathbf{2}$ & $0,35 \pm 0,01 \mathrm{ab}$ & $0,24 \pm 0,02 \mathrm{bc}$ & $0,19 \pm 0,01 \mathrm{ab}$ \\
Kertas coklat & $\mathbf{4} \pm \mathbf{2}$ & $0,35 \pm 0,00 \mathrm{bc}$ & $0,25 \pm 0,06 \mathrm{c}$ & $0,24 \pm 0,01 \mathrm{bc}$ \\
Polipropilen & $\mathbf{2 7} \pm \mathbf{2}$ & $0,40 \pm 0,00 \mathrm{bcd}$ & $0,36 \pm 0,03 \mathrm{c}$ & $0,34 \pm 0,02 \mathrm{bcd}$ \\
Polietilen & $\mathbf{2 7} \pm \mathbf{2}$ & $0,40 \pm 0,01 \mathrm{~cd}$ & $0,30 \pm 0,04 \mathrm{~d}$ & $0,27 \pm 0,01 \mathrm{cde}$ \\
Aluminium foil & $\mathbf{2 7} \pm \mathbf{2}$ & $0,42 \pm 0,00 \mathrm{~d}$ & $0,38 \pm 0,03 \mathrm{~d}$ & $0,35 \pm 0,02 \mathrm{de}$ \\
Kertas coklat & $\mathbf{2 7} \pm \mathbf{2}$ & $0,38 \pm 0,01 \mathrm{~d}$ & $0,32 \pm 1,18 \mathrm{~d}$ & $0,30 \pm 0,00 \mathrm{e}$ \\
\hline
\end{tabular}

Keterangan : Angka yang diikuti huruf sama pada baris yang sama menunjukkan Berpengaruh nyata $(\mathrm{P}<0,05)$.

Total karotenoid bubuk buah pandan yang belum diperlakukan (kontrol) adalah $0,40 \%$ penurunan total karoten untuk masingmasing perlakuan yaitu polipropilen $4^{\circ} \pm 2^{\circ} \mathrm{C}$, polietilen $4^{\circ} \pm 2^{\circ} \mathrm{C}$, aluminium foil $4^{\circ} \pm 2^{\circ} \mathrm{C}$, kertas coklat $4^{\circ} \pm 2^{\circ} \mathrm{C}$, polipropilen $27^{\circ} \pm 2^{\circ} \mathrm{C}$, polietilen $27^{\circ} \pm 2^{\circ} \mathrm{C}$, aluminium foil $27^{\circ} \pm 2^{\circ} \mathrm{C}$, kertas coklat $27^{\circ} \pm 2^{\circ} \mathrm{C}$ dari kontrol hingga minggu keempat berturut-turut adalah $35,71 \%, 51,19 \%, 55,95 \%, 44,05 \%, 20,24 \%$, $36,90 \%, 17,86 \%$ dan $28,57 \%$. Perlakuan aluminium foil $4^{\circ} \pm 2^{\circ} \mathrm{C}$ merupakan perlakuan yang mengakibatkan penurunan total karotenoid terkecil yaitu sebesar 17,86\%.

Tabel 5. Rerata \% total karotenoid bubuk buah pandan pada minggu ke- 2.

\begin{tabular}{lccc}
\hline \multirow{2}{*}{ Jenis kemasan } & \multicolumn{2}{c}{ Minggu ke- 2 } & Rerata \\
\cline { 2 - 4 } & $\mathbf{4}$ & $\mathbf{2 7}$ & \\
\hline Puhu( $\left.{ }^{\mathbf{O}} \mathbf{C}\right)$ & 0,39 & $0,76 \mathrm{a}$ \\
Polipropilen & 0,37 & 0,35 & $0,65 \mathrm{ab}$ \\
Aluminium foil & 0,30 & 0,40 & $0,71 \mathrm{bc}$ \\
Kertas coklat & 0,31 & 0,37 & $0,67 \mathrm{c}$ \\
\hline Rerata & 0,31 & $1,50 \mathrm{~b}$ & \\
\hline
\end{tabular}

Keterangan: Angka yang diikuti huruf sama pada kolom yang sama menunjukkan berpengaruh tidak nyata $(\mathrm{P}>0,05)$.

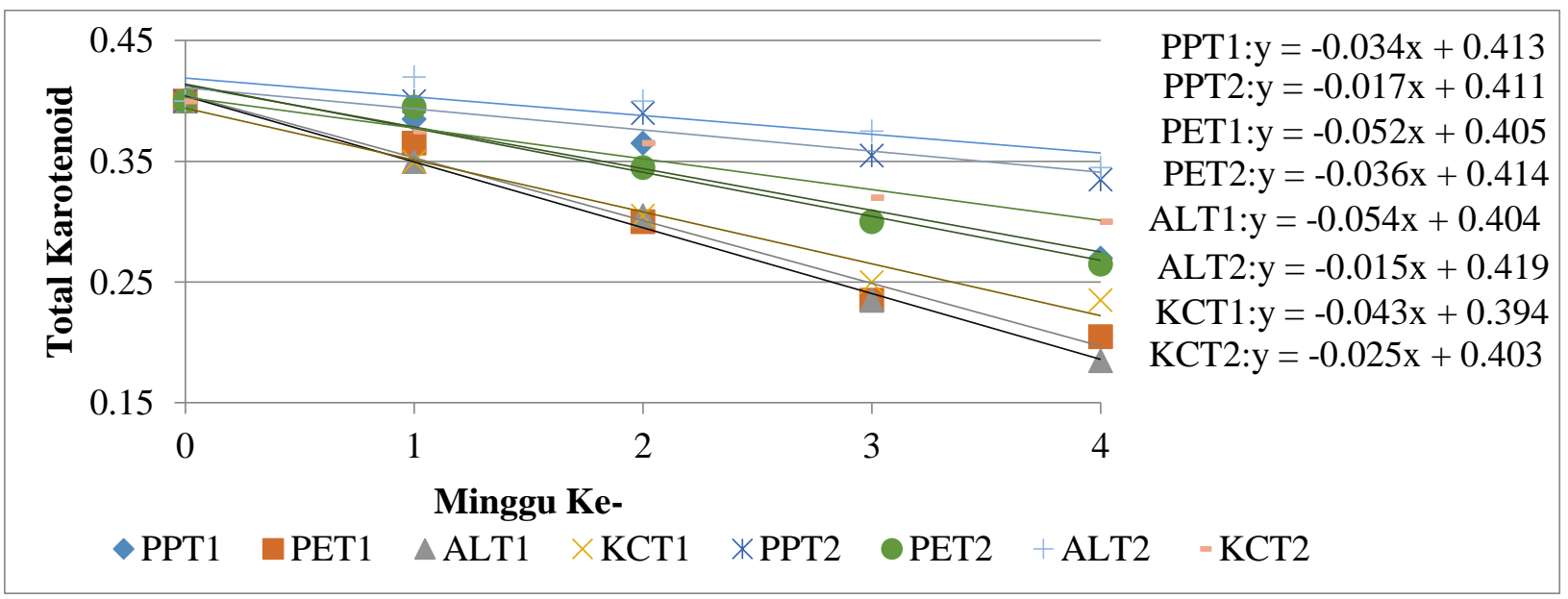


Gambar 2. Grafik penurunan total karotenoid bubuk buah pandan selama penyimpanan pada perlakuan jenis kemasan dan suhu penyimpanan.

Hal ini menunjukkan bubuk buah pandan paling stabil pada perlakuan tersebut. Selain itu karotenoid juga lebih stabil pada penyimpanan dengan kondisi suhu yang rendah (Arimboor dan Ramesh, 2015). Perlakuan kertas coklat $4^{\circ} \pm 2^{\circ} \mathrm{C}$ menunjukkan penurunan total karotenoid terbesar dibandingkan perlakuan lainnya yaitu sebesar $55,95 \%$. Hal ini menunjukkan bahwa karotenoid pada bubuk buah pandan paling tidak stabil pada perlakuan tersebut. Karotenoid merupakan salah satu pigmen yang memiliki sifat yang mudah mengalami isomerisasi pada kondisi asam maupun basa (Wahyuni dan Widjanarko, 2015). Isomerisasi ini dapat mengakibatkan perubahan struktur karotenoid dari trans menjadi bentuk cis. Menurut de Fretes et al. (2012), karotenoid dalam bentuk trans memiliki aktivitas dan intensitas warna yang lebih tinggi dibandingkan karotenoid dalam bentuk cis. Isomerisasi karotenoid dari trans menjadi cis mengakibatkan senyawa karotenoid lebih tidak stabil dan lebih mudah mengalami oksidasi yang dapat mengakibatkan degradasi (Ladislav et al., 2005). Oksidasi pada karotenoid mengakibatkan perubahan senyawa mulai dari terbentuknya senyawa epoksi hingga terbentuknya senyawa karotenoid baru yang memiliki aktivitas yang lebih rendah (Rodriguez dan Amaya, 2001). Selain itu, karotenoid juga memiliki karakteristik yang cenderung lebih stabil pada suhu yang lebih rendah. Adanya panas dan oksidasi akan mengakibatkan reaksi pemutusan pada ikatan rangkap terkojugasi pada molekul karotenoid yang mengakibatkan penurunan aktivitas dan degradasi karotenoid.

\section{Warna $L^{*}$}

Nilai $\mathrm{L}^{*}$ menyatakan tingkat kecerahan, yaitu gelap hingga terang dengan rentan nilai 0-100 (Indrayanti et al., 2013). Semakin besar nilai $\mathrm{L}^{*}$ maka tingkat kecerahan semakin tinggi. Analisis ragam pada nilai kecerahan menunjukkan bahwa perlakuan suhu dan jenis kemasan berpengaruh tidak nyata( $\mathrm{P}>0,05)$. Menurut Erawati 2006 tentang kendali stabilitas betakaroten selama proses produksi tepung ubi jalar (Ipomea batatas L.) yang menyatakan bahwa nilai kecerahan $\left(\mathrm{L}^{*}\right)$ pada tepung ubi jalar yang semakin terang $\left(\mathrm{L}^{*}\right.$ semakin tinggi) mengindikasikan proses kerusakan struktur trans betakaroten yang semakin besar. Data rata-rata dan grafik kenaikan nila kecerahan $\left(\mathrm{L}^{*}\right)$ bubuk buah pandan tiap minggunya, dilihat pada Tabel 6.

Tabel 6. Rerata intensitas warna ( $\left.\mathrm{L}^{*}\right)$ bubuk buah pandan pada minggu ke- 1 sampai minggu 4.

\begin{tabular}{lccccc}
\hline \multirow{2}{*}{ Jenis kemasan } & \multirow{2}{*}{ Suhu $\left.^{\circ} \mathbf{C}\right)$} & \multicolumn{4}{c}{ Waktu simpan(Minggu ke-) } \\
\cline { 3 - 6 } & & $\mathbf{1}$ & $\mathbf{2}$ & $\mathbf{3}$ & $\mathbf{4}$ \\
\hline Polipropilen & $\mathbf{4} \mathbf{2}$ & $55,35 \pm 21,00 \mathrm{a}$ & $66,40 \pm 4,10 \mathrm{a}$ & $64,40 \pm 10,18 \mathrm{a}$ & $65,20 \pm 2,55 \mathrm{a}$ \\
Polietilen & $\mathbf{4} \pm \mathbf{2}$ & $53,15 \pm 6,01 \mathrm{a}$ & $73,15 \pm 1,91 \mathrm{a}$ & $62,80 \pm 2,83 \mathrm{a}$ & $61,75 \pm 3,75 \mathrm{a}$ \\
Aluminium foil & $\mathbf{4} \pm \mathbf{2}$ & $60,30 \pm 7,07 \mathrm{a}$ & $59,60 \pm 0,28 \mathrm{a}$ & $65,10 \pm 5,66 \mathrm{a}$ & $67,85 \pm 9,12 \mathrm{a}$ \\
Kertas coklat & $\mathbf{4} \pm \mathbf{2}$ & $61,65 \pm 0,35 \mathrm{a}$ & $55,40 \pm 3,11 \mathrm{a}$ & $67,50 \pm 4,38 \mathrm{a}$ & $63,80 \pm 9,62 \mathrm{a}$ \\
Polipropilen & $\mathbf{2 7} \pm \mathbf{2}$ & $62,60 \pm 10,89 \mathrm{a}$ & $70,15 \pm 4,60 \mathrm{a}$ & $70,40 \pm 8,49 \mathrm{a}$ & $73,90 \pm 3,82 \mathrm{a}$ \\
Polietilen & $\mathbf{2 7} \pm \mathbf{2}$ & $62,75 \pm 5,44 \mathrm{a}$ & $78,00 \pm 2,12 \mathrm{a}$ & $72,00 \pm 7,64 \mathrm{a}$ & $73,90 \pm 4,10 \mathrm{a}$ \\
Aluminium foil & $\mathbf{2 7} \pm \mathbf{2}$ & $65,90 \pm 0,71 \mathrm{a}$ & $65,85 \pm 0,21 \mathrm{a}$ & $67,70 \pm 3,25 \mathrm{a}$ & $76,10 \pm 0,71 \mathrm{a}$ \\
Kertas coklat & $\mathbf{2 7} \pm \mathbf{2}$ & $66,10 \pm 0,14 \mathrm{a}$ & $61,80 \pm 1,27 \mathrm{a}$ & $70,80 \pm 1,41 \mathrm{a}$ & $68,95 \pm 7,57 \mathrm{a}$ \\
\hline
\end{tabular}

Keterangan: Angka yang diikuti huruf sama pada baris menunjukkan berpengaruh tidak nyata $(\mathrm{P}>0,05)$. 


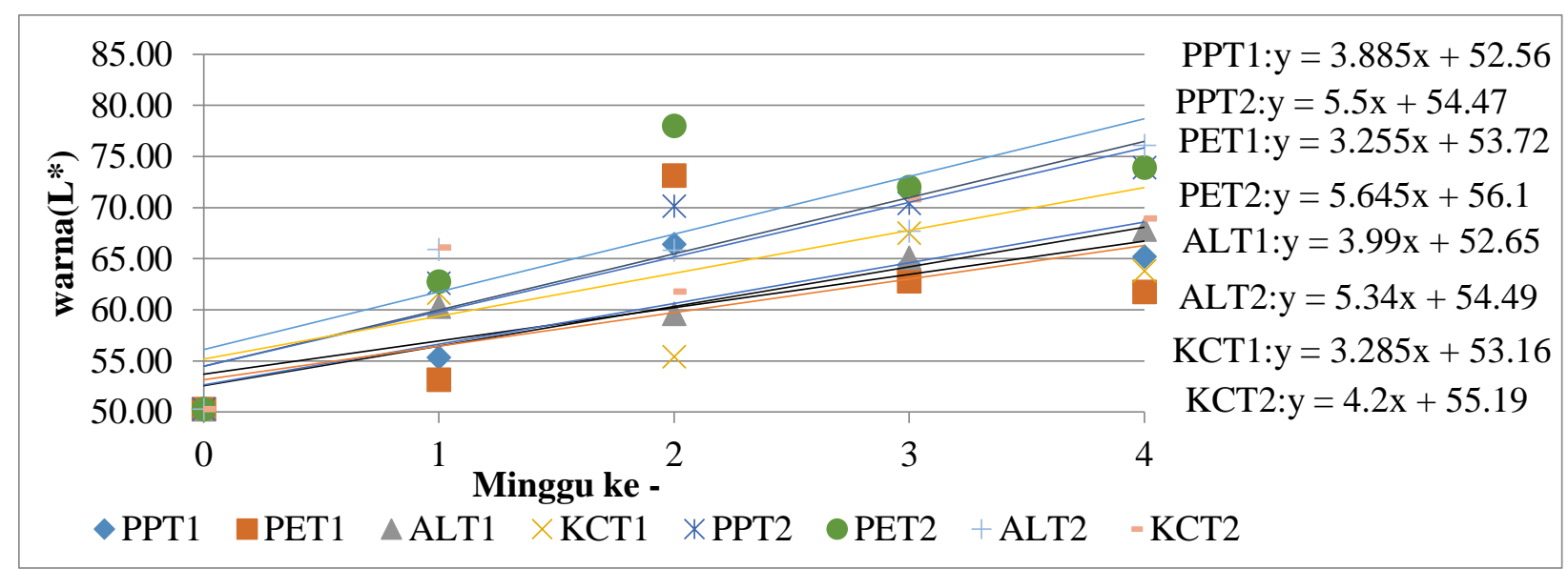

Gambar 3. Grafik peningkatan warna L bubuk buah pandan selama penyimpanan pada perlakuan jenis kemasan dan suhu penyimpanan.

Intensitas warna (L) bubuk buah pandan yang belum diperlakukan (kontrol) adalah $50,30 \%$ kenaikan nilai kecerahan untuk masing-masing perlakuan polipropilen $4^{\circ} \pm 2^{\circ} \mathrm{C}$, polietilen $4^{\circ} \pm 2^{\circ} \mathrm{C}$, aluminium foil $4^{\circ} \pm 2^{\circ} \mathrm{C}$, kertas coklat $4^{\circ} \pm 2^{\circ} \mathrm{C}$, polipropilen $27^{\circ} \pm 2^{\circ} \mathrm{C}$, polietilen $27^{\circ} \pm 2^{\circ} \mathrm{C}$, aluminium foil $27^{\circ} \pm 2^{\circ} \mathrm{C}$, kertas coklat $27^{\circ} \pm 2^{\circ} \mathrm{C}$ dari kontrol hingga minggu ke-4 berturut-turut adalah $29,62 \%, 22,76 \%, 34,89 \%, 26,84 \%, 46,92 \%$, $46,92 \%, 51,29 \%$ dan $37,08 \%$ Kenaikan nilai $\mathrm{L}^{*}$ terkecil diperoleh pada perlakuan polietilen $4^{\circ} \pm 2^{\circ} \mathrm{C}$ yaitu sebesar $22,76 \%$. Menurut Wahyuni dan Widjanarko (2015), kandungan pigmen dalam suatu bahan akan mempengaruhi nilai kecerahannya. Penelitian Erawati (2006) menyatakan bahwa nilai kecerahan pada tepung ubi jalar yang mengandung karotenoid semakin meningkat selama penyimpanan. Sehingga semakin tinggi pigmen karotenoid dalam ekstrak maka nilai kecerahan akan semakin rendah(gelap). Menurut Eskin (1989), karotenoid mudah terkena oksidasi akibat adanya cahaya yang menyebabkan kehilangan warna.

\section{Tingkat kemerahan $\mathbf{a}^{*}$}

Nilai kemerahan $\left(a^{*}\right)$ merupakan indikator untuk warna hijau hingga merah. Nilai a yang negatif menunjukkan warna hijau dan nilai a yang positif menunjukkan warna merah (Indrayanti et al., 2013).
Analisis ragam pada nilai kemerahan $\left(\mathrm{a}^{*}\right)$ menunjukkan bahwa perlakuan antara suhu dan kemasan tidak berpengaruh nyata pada setiap minggunya $(\mathrm{P}>0,05)$. Perlakuan kemasan berpengaruh nyata pada minggu ke$3 \quad(\mathrm{P}<0,05)$ dan perlakuan suhu tidak berpengaruh nyata pada setiap minggunya $(p>0,05)$. Nilai rata- rata dan grafik penurunan tingkat kemerahan $\left(\mathrm{a}^{*}\right)$ bubuk buah pandan untuk masing- masing perlakuan selama penyimpanan dapat dilihat pada Tabel 7.

Intensitas warna $\left(\mathrm{a}^{*}\right)$ bubuk buah pandan yang belum diperlakukan (kontrol) adalah $13,9 \%$. Penurunan nilai kemerahan untuk masing-masing perlakuan polipropilen polipropilen $4^{\circ} \pm 2^{\circ} \mathrm{C}$, polietilen $4^{\circ} \pm 2^{\circ} \mathrm{C}$, aluminium foil $4^{\circ} \pm 2^{\circ} \mathrm{C}$, kertas coklat $4^{\circ} \pm 2^{\circ} \mathrm{C}$,polipropilen $27^{\circ} \pm 2^{\circ} \mathrm{C}$, polietilen $27^{\circ} \pm 2^{\circ} \mathrm{C}$, aluminium foil $27^{\circ} \pm 2^{\circ} \mathrm{C}$, kertas coklat $27^{\circ} \pm 2^{\circ} \mathrm{C}$ dari kontrol hingga minggu ke- 4 berturut-turut adalah 52,88\%, 59,35\%, $43,88 \%, 30,22 \%, 50,72 \%, 54,32 \%, 32,01$ dan $34,89 \%$. Penurunan nilai a* terkecil diperoleh pada perlakuan kertas coklat $4^{\circ} \pm 2^{\circ} \mathrm{C}$ yaitu sebesar $30,22 \%$. Penurunan nilai a* terbesar diperoleh pada polipropilen $4^{\circ} \pm 2^{\circ} \mathrm{C}$ sebesar $59,35 \%$. Penurunan nilai $\mathrm{a}^{*}$ terjadi dikarenakan bubuk buah pandan mengalami perubahan warna kehijauan disebabkan terjadinya penurunan kadar total karoten terhadap bubuk buah pandan. 
Tabel 7. Rerata intensitas warna (a*) bubuk buah pandan pada minggu ke- 1 sampai minggu 4.

\begin{tabular}{lccccc}
\hline \multirow{2}{*}{ Jenis kemasan } & \multirow{2}{*}{ Suhu $\left({ }^{\circ} \mathbf{C}\right)$} & \multicolumn{4}{c}{ Waktu simpan(Minggu ke-) } \\
\cline { 3 - 6 } & & $\mathbf{1}$ & $\mathbf{2}$ & $\mathbf{3}$ & $\mathbf{4}$ \\
\hline Polipropilen & $\mathbf{4 \pm 2}$ & $8,80 \pm 5,23 \mathrm{a}$ & $8,10 \pm 0,57 \mathrm{a}$ & $7,5 \pm 2,26 \mathrm{a}$ & $6,55 \pm 0,92 \mathrm{a}$ \\
Polietilen & $\mathbf{4 \pm 2}$ & $9,30 \pm 3,11 \mathrm{a}$ & $7,45 \pm 0,49 \mathrm{a}$ & $6,8 \pm 1,27 \mathrm{a}$ & $5,65 \pm 1,63 \mathrm{a}$ \\
Aluminium foil & $\mathbf{4 \pm 2}$ & $8,30 \pm 1,41 \mathrm{a}$ & $6,90 \pm 1,56 \mathrm{a}$ & $7,1 \pm 1,70 \mathrm{a}$ & $7,80 \pm 2,12 \mathrm{a}$ \\
Kertas coklat & $\mathbf{4} \pm \mathbf{2}$ & $8,80 \pm 1,56 \mathrm{a}$ & $6,20 \pm 3,82 \mathrm{a}$ & $8,2 \pm 0,21 \mathrm{a}$ & $10,70 \pm 1,27 \mathrm{a}$ \\
Polipropilen & $\mathbf{2 7 \pm 2}$ & $8,40 \pm 1,84 \mathrm{a}$ & $6,20 \pm 1,27 \mathrm{a}$ & $8,6 \pm 3,46 \mathrm{a}$ & $6,85 \pm 0,92 \mathrm{a}$ \\
Polietilen & $\mathbf{2 7 \pm 2}$ & $7,45 \pm 1,91 \mathrm{a}$ & $7,50 \pm 0,99 \mathrm{a}$ & $9,4 \pm 1,41 \mathrm{a}$ & $6,35 \pm 1,77 \mathrm{a}$ \\
Aluminium foil & $\mathbf{2 7} \pm \mathbf{2}$ & $9,00 \pm 1,41 \mathrm{a}$ & $5,60 \pm 0,00 \mathrm{a}$ & $7,4 \pm 1,41 \mathrm{a}$ & $9,45 \pm 0,21 \mathrm{a}$ \\
Kertas coklat & $\mathbf{2 7} \pm \mathbf{2}$ & $9,00 \pm 0,57 \mathrm{a}$ & $8,10 \pm 1,56 \mathrm{a}$ & $8,25 \pm 1,48 \mathrm{a}$ & $13,10 \pm 2,97 \mathrm{a}$ \\
\hline
\end{tabular}

Keterangan: Angka yang diikuti huruf sama pada baris menunjukkan berpengaruh tidak nyata $(\mathrm{P}>0,05)$.

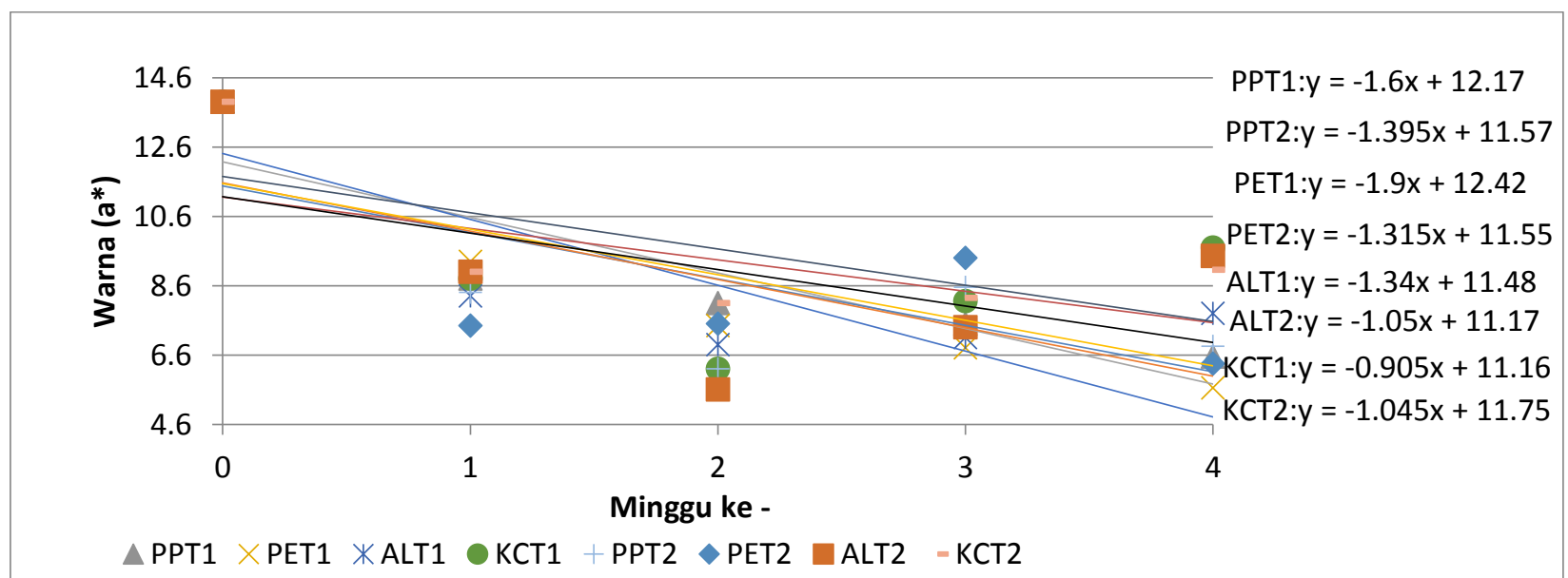

Gambar 4. Grafik penurunan nilai kemerahan (a*) bubuk buah pandan selama penyimpanan pada perlakuan kemasan dan suhu.

\section{Warna $b^{*}$}

Nilai $b^{*}$ pada uji intensitas warna merupakan indikator warna dari biru hingga kuning. Nilai b* akan menunjukan warna biru apabila bernilai negatif. Apabila nilai $b^{*}$ bernilai positif maka menunjukkan warna kuning. Nilai $b^{*}$ yang positif yang menunjukkan bahwa bubuk buah pandan yang diperoleh memiliki pigmen berwarna kuning. Analisis ragam untuk nilai kekuningan $\left(b^{*}\right)$ menunjukkan perlakuan suhu berpengaruh tidak nyata pada setiap minggunya $(\mathrm{P}>0,05)$. Perlakuan jenis kemasan dan suhu selama penyimpanan menunjukan berpengaruh tidak nyata pada setiap minggunya $(\mathrm{P}>0,05)$ pada bubuk buah pandan. Sesuai dengan penelitian Gusdinar $e t$ al. (2011) pada pengujian stabilitas pigmen karatenoid dari Neurospora intermedia N-1, dimana nilai kekuningan dari serbuk pigmen karatenoid mengalami penurunan saat masa simpan. Berkurangnya nilai kekuningan menunjukkan terjadinya degradasi pigmen karatenoid dalam suatu bahan. Selain pigmen karatenoid juga akan lebih mudah mengalami kerusakan pada suhu tinggi karena terjadinya degradasi akibat panas (thernal degradation) (Lubi et al., 2012). Hasil pengamatan terhadap perubahan nilai $\left(b^{*}\right)$ dapat dilihat pada tabel 8 . 
Tabel 8. Rerata intensitas warna ( $\mathrm{b}^{*}$ ) bubuk buah pandan pada minggu ke- 1 sampai minggu 4.

\begin{tabular}{lccccc}
\hline \multirow{2}{*}{ Jenis kemasan } & \multirow{2}{*}{ Suhu $\left({ }^{\mathbf{}} \mathbf{C}\right)$} & \multicolumn{4}{c}{ Waktu simpan(Minggu ke-) } \\
\cline { 3 - 6 } & & $\mathbf{1}$ & $\mathbf{2}$ & $\mathbf{3}$ & $\mathbf{4}$ \\
\hline Polipropilen & $\mathbf{4} \mathbf{2}$ & $30,50 \pm 0,28 \mathrm{a}$ & $26,80 \pm 3,39 \mathrm{a}$ & $25,20 \pm 0,42 \mathrm{a}$ & $23,50 \pm 6,22 \mathrm{a}$ \\
Polietilen & $\mathbf{4} \pm \mathbf{2}$ & $25,65 \pm 2,19 \mathrm{a}$ & $24,75 \pm 1,63 \mathrm{a}$ & $29,45 \pm 1,77 \mathrm{a}$ & $22,80 \pm 0,85 \mathrm{a}$ \\
Aluminium foil & $\mathbf{4 \pm 2}$ & $26,75 \pm 1,34 \mathrm{a}$ & $28,55 \pm 2,19 \mathrm{a}$ & $27,70 \pm 1,84 \mathrm{a}$ & $23,75 \pm 1,91 \mathrm{a}$ \\
Kertas coklat & $\mathbf{4} \mathbf{2}$ & $27,60 \pm 4,38 \mathrm{a}$ & $29,40 \pm 2,69 \mathrm{a}$ & $28,55 \pm 2,76 \mathrm{a}$ & $25,70 \pm 0,99 \mathrm{a}$ \\
Polipropilen & $\mathbf{2 7 \pm 2}$ & $28,80 \pm 1,56 \mathrm{a}$ & $26,90 \pm 0,14 \mathrm{a}$ & $27,30 \pm 0,85 \mathrm{a}$ & $24,50 \pm 0,42 \mathrm{a}$ \\
Polietilen & $\mathbf{2 7 \pm 2}$ & $26,10 \pm 1,84 \mathrm{a}$ & $27,50 \pm 2,40 \mathrm{a}$ & $23,10 \pm 1,13 \mathrm{a}$ & $24,65 \pm 0,49 \mathrm{a}$ \\
Aluminium foil & $\mathbf{2 7 \pm 2}$ & $27,25 \pm 2,33 \mathrm{a}$ & $27,30 \pm 3,68 \mathrm{a}$ & $27,90 \pm 1,13 \mathrm{a}$ & $25,75 \pm 0,78 \mathrm{a}$ \\
Kertas coklat & $\mathbf{2 7 \pm 2}$ & $30,50 \pm 1,98 \mathrm{a}$ & $30,05 \pm 1,34 \mathrm{a}$ & $28,00 \pm 3,82 \mathrm{a}$ & $27,75 \pm 3,04 \mathrm{a}$ \\
\hline
\end{tabular}

Keterangan: Angka yang diikuti huruf sama pada baris menunjukkan berpengaruh tidak nyata $(\mathrm{P}>0,05)$.

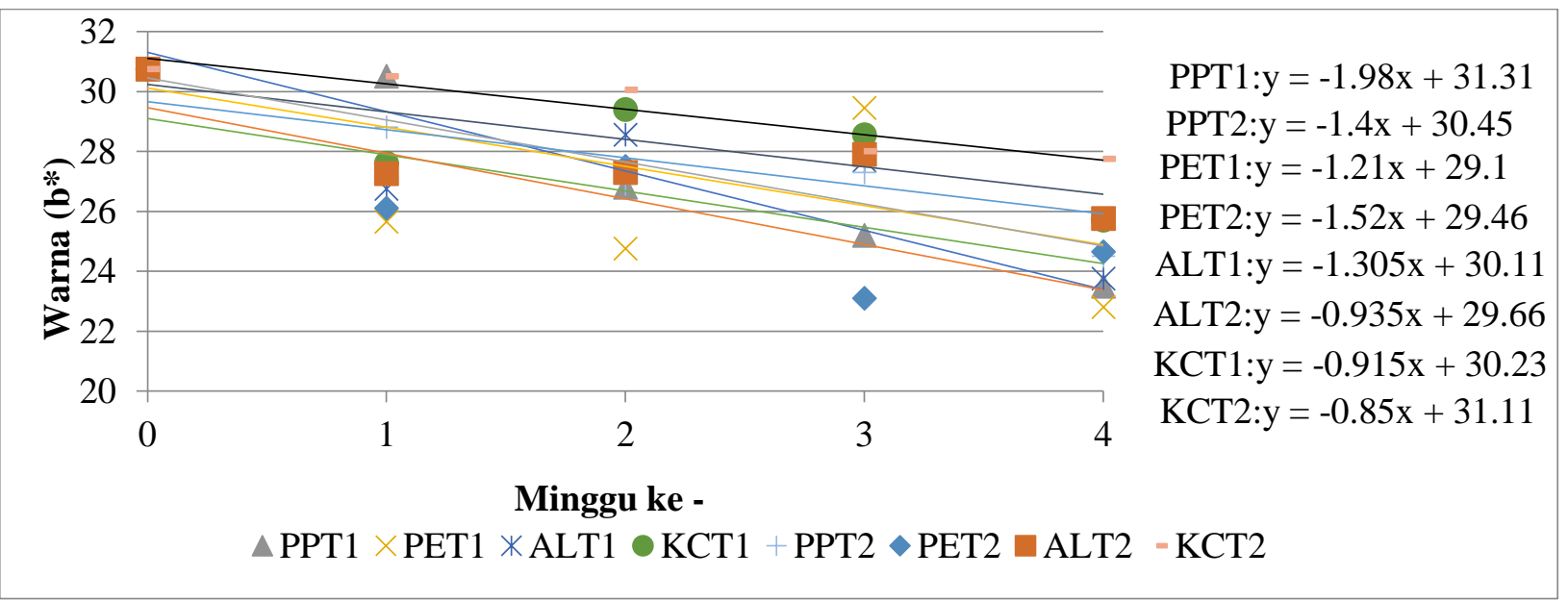

Gambar 5. Grafik penurunan nilai kekuningan ( $\left.b^{*}\right)$ bubuk buah pandan selama penyimpanan pada perlakuan kemasan dan suhu.

Intensitas warna $\left(b^{*}\right)$ bubuk buah pandan yang belum diperlakukan (kontrol) adalah $30,75 \%$. Penurunan nilai kekuningan untuk masing-masing perlakuan yaitu polipropilen $4^{\circ} \pm 2^{\circ} \mathrm{C}$, polietilen $4^{\circ} \pm 2^{\circ} \mathrm{C}$, aluminium foil $4^{\circ} \pm 2^{\circ} \mathrm{C}$, kertas coklat $4^{\circ} \pm 2^{\circ} \mathrm{C}$, polipropilen $27^{\circ} \pm 2^{\circ} \mathrm{C}$, polietilen $27^{\circ} \pm 2^{\circ} \mathrm{C}$, aluminium foil $27^{\circ} \pm 2^{\circ} \mathrm{C}$, kertas coklat $27^{\circ} \pm 2^{\circ} \mathrm{C}$ berturut-turut adalah $23,58 \%$, $22,60 \%, 22,76 \%, 16,42 \%, 20,33 \%, 19,84 \%$, $16,26 \%$ dan $9,76 \%$. Penurunan $b^{*}$ terkecil diperoleh pada perlakuan kertas coklat $27 \pm 2^{\circ} \mathrm{C}$ yaitu sebesar $9,76 \%$. Penurunan nilai $\mathrm{b}^{*}$ terbesar diperoleh pada perlakuan polipropilen $4 \pm 2^{\circ} \mathrm{C}$ yaitu sebesar $23,58 \%$. Hal ini menunjukkan bahwa pigmen karotenoid yang disimpan dengan perlakuan kertas coklat dan suhu ruang $\left(27^{\circ} \pm 2^{\circ} \mathrm{C}\right)$ paling sedkit mengalami kerusakan dibandingkan perlakuan lainnya. Pigmen karotenoid memiliki tingkat kestabilan lebih tinggi dengan penyimpanan kondisi suhu yang rendah (Arim Boor dan Ramesh, 2015). Grafik penurunan nilai kekuningan pada Gambar 5 menunjukan bahwa nilai perlakuan PPT2 dan suhu ruang $27^{\circ} \pm 2^{\circ} \mathrm{C}$ merupakan nilai penurunan terkecil yaitu sebesar 0,305 sedangkan nilai penurunan kekuningan tertinggi diperoleh pada perlakuan polietilen $4^{\circ} \pm 2^{\circ} \mathrm{C}$ yaitu sebesar 0,88 . Hal ini diduga degradasi karotenoid yang menghasilkan senyawa tidak berwarna, hal tersebut dapat terjadi sebagai akibat dari putusnya ikatan rangkap dalam struktur molekulnya. Penurunan warna kuning dari karotenoid selama penyimpanan dapat disebabkan oleh 
degradasi trans dan formasinya kebentuk isomer cis. Telah banyak dilaporkan bahwa formasi cis karotenoid dapat menurunkan intensitas warna. Studi yang dilakukan Chen dan Tang (1988), meyebutkan bahwa penurunan nilai $L^{*}, a^{*}$ dan $b^{*}$ dalam serbuk karotenoid akan menurun seiring dengan meningkatnya waktu penyimpanan.

\section{KESIMPULAN DAN SARAN}

\section{Kesimpulan}

Berdasarkan penelitian yang telah dilakukan maka dapat disimpulkan jenis kemasan dan suhu penyimpanan berpengaruh nyata $(\mathrm{P}<0,05)$ terhadap kadar total Karotenoid pada minggu ke 1,3 dan 4 pada kadar air minggu ke 2 dan ke 3 berpengaruh sangat nyata $(\mathrm{P}<0,01)$ dan berpengaruh tidak sangat nyata $(\mathrm{P}>0,05)$ terhadap karoten minggu ke 2, kadar air minggu ke 1 dan 4 , intensitas warna $\mathrm{L}$ (tingat kecerahan), $\mathrm{a}^{*}$ (tingkat kemerahan), $\mathrm{b}^{*} \quad$ (tingkat kekuningan). Perlakuan terbaik untuk mempertahankan karakteristik bubuk buah pandan adalah kemasan aluminium foil dan disimpan pada suhu $4^{\circ} \pm 2^{\circ} \mathrm{C}$ dengan kadar air, total karoten, intesitas warna $\mathrm{L}^{*}, \mathrm{a}^{*}, \mathrm{~b}^{*}$ bubuk buah pandan berturut turut $14,00 \%$, $17,86 \%, 34,89 \%, 43,88 \%, 22,76 \%$.

\section{Saran}

Penelitian lebih lanjut perlu dilakukan pada bubuk buah pandan untuk disimpan pada kemasan aluminium dan pada suhu $4^{\circ} \pm 2^{\circ} \mathrm{C}$, salah satunya dengan mempertimbangkan faktor lain seperti pengemasan ganda untuk penyimpanan bubuk buah pandan yang terbaik.

\section{DAFTAR PUSTAKA}

Andriyani, M. D., E. N. Dewi, dan E. Susanto. 2016. Stabilitas ekstrak pigmen lamun laut (Enhalus acoroides) dari perairan teluk Awur Jepara terhadap suhu dan lama penyimpanan. Prosiding Seminar Nasional HasilHasil Penelitian Perikanan dan Kelautan. 6: 384-400.

Antari, N.M.R.O., N.M. Wartini, dan S. Mulyani. 2015. Pengaruh ukuran partikel dan lama ekstraksi terhadap karakteristik ekstrak warna alami buah pandan. Jurnal Rekayasa dan Manajemen Agroindustri. 3 (4) :1-4.

Aryayustama, M. G., N. M. Wartini., dan N. P. Suwariani. 2018. Pengaruh Cahaya dan Suhu Terhadap Stabilitas Ekstrak Buah Pandan (Pandanus tectorius). Jurnal Rekayasa Proses dan Manajemen Agroindustri. 4 (3) : V

BPPHP.2002.Penanganan pascapanen dan pengemasan

sayuran.http://agribisnis.deptan.go.id/2 8 Desember 2012.

Cahayanti, I. A. P. A., N. M. Wartini, dan L. P. Wrasiati. 2015. Pengaruh suhu dan waktu ekstraksi terhadap karakteristik pewarna alami buah pandan (Pandanus tectorius). Jurnal Rekayasa dan Manajemen Agroindustri. 4 (2) :1-4.

Erawati, C. M. 2006. Kendali Stabilitas Beta Karoten Selama Proses Produksi Tepung Ubi Jalar (Ipomoea batatas L.). Tesis S2. Tidak dipublikasikan. Program Pasca Sarjana IPB, Bogor.

Gusdinar T., M. Singgihi, S. Priatni, Sukmawati AE., dan T. Suciati. 2011. Enkapsulasi dan stabilitas pigmen karotenoid dari Neurospora intermedia N-1. Jurnal Manusia dan Lingkungan. 18(3): 206-211.

Indrayati, F., R. Utami, dan E. Nurhartadi. 2013. Pengaruh penambahan minyak atsiri kunyit putih (Kaempferia rotunda) pada edible coating terhadap stabilitas warna dan $\mathrm{pH}$ fillet ikan patin 
yang disimpan pada suhu beku. Jurnal Teknosains Pangan. 4 (2): 25-31.

Indriyani, N. M. D., N. M. Wartini., dan N. P. Suwariani. 2018. Pengaruh $\mathrm{pH}$ dan Suhu Penyimpanan Terhadap Stabilitas Ekstrak dari Buah Pandan (Pandanus tectorius). Jurnal Rekayasa Proses dan Manajemen Agroindustri. 3 (4) : V

Lubis, E. H., H. Wijaya, dan N. Lestari. 2012. Mempelajari ekstraksi dan stabilitas total karotenoid, $\alpha$ dan $\beta$ cryptoxanthin dalam ekstrak buah merah (Pandanus conoidieus, Lmak). Jurnal Riset Teknologi Industri. 6 (12): 39-53.

Muhammad Shahnawaz, Saghir Ahmed Sheikh, Aijaz Hussain Soomro, Aasia Akbar Panhwar and Shahzor Gul Khaskheli. 2012. Quality characteristics of tomatoes (lycopersicon esculentum) stored in various wrapping materials. African Journal of Food Science and Technology (ISSN: 2141-5455) Vol. 3(5) pp.

Oktafia, S., H. Soetjipto., dan L. N. Lestario. 2015. Pengaruh $\mathrm{pH}$ dan intensitas cahaya terhadap kestabilan ekstrak karotenoid kulit buah alkesa (Pouteria campechiana (Kunth.) Baehni). Fakultas Sains dan Matematika, Universitas Kristen Satya Wacana, Salatiga. 1-16.

Ratih, N. G. A. K., N. M. Wartini., dan I. W. G. S. Yoga. 2015. Pengaruh Jenis Pelarut Terhadap Rendemen dan Karakteristik Ekstrak Pewarna dari Buah Pandan (Pandanus tectorius). Jurnal Rekayasa dan Manajemen Agroindustri, 3 (4) :1-4.

Rohman A, Riyanto S, Yuniarti N, Saputra WR, dan Mulatsih W. 2010. Antioxidant activity, total flavonoid, and total phenolic of extracts and fraction of fruit (Pandanus conoideus).
International Food Research Journal. 17: 97-106.

Rochman.2007.Kajian Teknik Pengemasan Buah Pepaya Dan Semangka Terolah Minimal Selama Penyimpanan Dingin. Fakultas Teknologi Pertanian Institut Pertanian Bogor. Bogor

Robertson, Gordon. L. 1993. Food Packaging : Principles and Practice. Marcel Dekker, Inc., New York.

Satriyanto, B., S.B. Widjanarko, dan Yunianta. 2012. Stabilitas warna ekstrak buah merah (Pandanus conoideus) terhadap pemanasan sebagai sumber potensial pigmen alami. J. Teknol Pertanian. 13 (3):157168.

Sudarmadji, S., B. Haryono., dan Suhardi. 1989. Analisa Bahan Makanan dan Pertanian. Penerbit Liberty. Yogyakarta

Meilgaard, M., G.V. Civille and B.T Carr., 1999. Sensory Evaluation Techniques $3^{\text {rd }}$ Edition. CRC Press. New York.

Muchtadi, D. 1989. Evaluasi Nilai Gizi Pangan. Departemen Pendidikan dan Kebudayaan Direktorat Jenderal Pendidikan Tinggi Pusat Antar Universitas Pangandan Gizi. Institut Pertanian Bogor.

Wahyuni, D. T., dan S. B. Widjanarko. 2015. Pengaruh jenis pelarut dan lama ekstraksi terhadap ekstrak karotenoid labu kuning dengan metode gelombang ultrasonik. Jurnal Pangan dan Agroindustri. 3 (2): 390-401.

Weaver, C. 1996. The Food Chemistry Laboratory. CRC Press, Boca Raton, New York, london, Tokyo.

Yudharini, G. A. K. F., A. A. P. A. Suryawan., dan N. M. Wartini. 2016. Pengaruh perbandingan bahan dengan 
pelarut dan lama ekstraksi terhadap rendemen dan karakteristik ekstrak pewarna dari buah pandan (Pandanus tectorius). Jurnal Rekayasa dan Manajemen Agroindustri, 4 (3) :1 - 4. 